\section{Doświadczenie bez nazwy. "Oświęcim" = Auschwitz}

Agnieszka Dauksza

TEKSTY DRUGIE 2016, NR 6, S. 233-249

DOI: $10.18318 /$ td.2016.6.13
Badania zostały dofinansowane przez Wydział Polonistyki Uniwersytetu Jagiellońskiego ze środków na działalność statutową WPUJ, służących rozwojowi młodych naukowców oraz uczestników studiów doktoranckich.
Dunktem wyjścia tego artykułu jest zdanie wypowiedziane przez Stefana Lipniaka - byłego więźnia obozu: „Zazdroszczę Żydom Holokaustu”. Szerszym kontekstem była rozmowa przeprowadzona w czerwcu 2015 roku - jedna z cyklu wywiadów z byłymi więźniami obozów koncentracyjnych, które miały złożyć się na przygotowywaną przeze mnie książkę ${ }^{1}$ Stefan Lipniak - widząc wówczas moje zdziwienie - powtórzył i doprecyzował swoją uwagę. Ten fragment naszej rozmowy brzmiał następująco:

- Żydy byli zawsze oddzielnie. Nigdy tak blisko między Polakami a Żydami nie było. Ale ja i tak im zazdroszczę.

- Co ma pan na myśli?

- Zazdroszczę Żydom Holokaustu.
Agnieszka Dauksza

- w Katedrze Antropologii Literatury i Badań Kulturowych WP UJ przygotowuje pracę doktorską poświęconą afektom w literaturze i sztuce modernizmu.

Autorka książek Klub Auschwitz i inne kluby. Rwane opowieści przeżywców (2016) i Kobiety na drodze. Doświadczenie przestrzeni publicznej w literaturze przełomu XIXiXX wieku (2013). Kontakt: agnieszka. dauksza@gmail.com

1 A. Dauksza Klub Auschwitz i inne kluby. Rwane opowieści przeżywców, słowo/obraz terytoria, Gdańsk 2016. 
- Słucham?

- Zazdroszczę im tego terminu Holokaust. Mocny jest.

- Dlaczego?

- Od razu wiadomo, o co chodzi. A my nie potrafiliśmy nazwać tego, co nas spotkało. „Wojna”, „obozy”, „niewola”? Tyle lat minęło, a my nie mamy nazwy.

- Ma pan jakiś pomysł?

- Kiedy właśnie nie mam. Ty byś czegoś nie wymyśliła, pani Agnieszko?

Z pewnością z perspektywy badań socjologicznych i antropologicznych można uznać te refleksje za pojedyncze, a co za tym idzie marginalne $i$ „niemiarodajne" źródło informacji. Jednak z jakichś względów to "przypadkowe" wyznanie i związany z nim ,słaby" imperatyw etyczny w miarę upływu czasu nurtują mnie coraz bardziej. Skłaniam się więc ku wstępnemu założeniu, by komentarz mojego rozmówcy potraktować jako jednostkową mikrodiagnozę funkcjonowania wspólnoty, jaką są polscy byli więźniowie obozów koncentracyjnych. Powstaje jednak pytanie, dlaczego przywiązuję wagę do tej wypowiedzi?

Otóż słuchając opowieści kolejnych rozmówców - więźniów kilku różnych obozów - odsłuchując wiele nagrań zdeponowanych w archiwach Ośrodka $K \operatorname{rara}^{2}$, a także czytając relacje spisane m.in. przez Piotra Filipkowskiego ${ }^{3}$, Pawła Grenia i Łukasza Posłusznego ${ }^{4}$, zdałam sobie sprawę, że słowa Stefana Lipniaka odwołują się do szerszych kręgów powojennego i współczesnego społeczeństwa i wprost wskazują na polski problem pamięciowo-tożsamościowy przez wielu odczuwany, uwewnętrzniany i na różne sposoby pośrednio komunikowany. Jest nim doświadczenie bez nazwy, czyli niemożność nazwania, a co za tym idzie, doświadczenia tego, co przydarzyło się znaczącej grupie Polaków podczas okupacji. Co więcej, kwestia dotyczy nie tylko faktycznych byłych więźniów i ich najbliższych włącznie z dziećmi i wnukami zgodnie z logiką postpamięciowej, transmisyjnej i narracyjnej wymiany - ale także tych, którzy przez kilka lat żyli w obawie przed deportacją do obozu oraz tych, którzy byli świadkami wywożenia innych, również Żydów. Generalnie

2 Baza świadectw dostępna jest na stronie: www.karta.org.pl.

3 P. Filipkowski Historia mówiona i wojna. Doświadczenie obozu koncentracyjnego w perspektywie narracji biograficznych, Wydawnictwo UWr, Wrocław 2010.

4 P. Greń, Ł. Posłuszny Pytanie o pamięć. Relacje autobiograficzne więźniów obozów koncentracyjnych, Aureus, Kraków 2012. 
rzecz biorąc, mowa więc o znacznej części polskiego społeczeństwa, które mentalnie nie uwolniło się od cienia instytucji obozu .

Na prawach eksperymentu poważam się na te tezy, gdyż chciałabym sprowokować - siebie i innych - do przemyślenia następujących kwestii: co właściwie chciał zakomunikować Stefan Lipniak, stwierdzając że „tyle lat minęło, a my nie mamy nazwy"? Z jakiej pozycji mówił? Przeciwko komu orzekał? Czego w gruncie rzeczy „zazdrości” instancji, którą określa mianem „Żydów”? Czym jest dla niego „Holokaust”? Dlaczego ten termin jest w jego mniemaniu „mocny” i na czym właściwie polega owa „moc"?

Mój rozmówca, urodzony w 1924 roku, pochodzący z Trzebini, po wojnie zamieszkały w Krakowie, był więźniem kilku hitlerowskich obozów koncentracyjnych: ZAL Klein Mangersdorf, karnego obozu pracy Rattwitz, obozu pracy Markstädt i KL Auschwitz III Monowitz, w których łącznie przebywał od 1941 do 1945 roku. Został zatrzymany 26 czerwca 1941 roku wskutek działań Organisation Schmelt, która na rozkaz oficera SS Albrechta Schmelta aresztowała i umieściła tysiące młodych Polaków i Żydów w obozach pracy na Górnym Śląsku. Przez cztery lata zniewolenia dwukrotnie podejmował próby ucieczki, drugi raz z powodzeniem, gdy wraz z kolegą Poldkiem Jaroszem oddalili się z transportu kolejowego po marszu śmierci w styczniu 1945 roku. Po wojnie został wcielony na ponad półtora roku do oddziału walczącego z oddziałami UPA na terenach bieszczadzkich. Cytowany przeze mnie fragment opowieści był kontynuacją wypowiedzi na temat stosunków polsko-żydowskich w przedwojennej Małopolsce, zwłaszcza w Trzebini. Stefan Lipniak wspominał o napiętych relacjach panujących w lokalnej społeczności, ogromnej biedzie mieszkańców Trzebini i zazdrości w stosunku do Żydów. Przyznał się również do sporadycznego uczestnictwa w spontanicznych chłopięcych napaściach na Żydów przewożących wozami drabiniastymi swoje towary na targ. Znamienne, że w wątkach dotyczących realiów przedwojennych wprost werbalizowany antysemityzm łączy się z resentymentem i z podziwem. Żydzi określani są mianem „superludzi” - mądrzejszych, zdolnych, lepiej wykształconych i bardziej zaradnych niż Polacy 5 .

Ewidentnie te odczucia zmieniają się w toku doświadczeń obozowych. W miejsce uznania i zazdrości pojawia się współczucie oraz przeświadczenie o jakiejś elementarnej ludzkiej, , ,cielesnej” wspólnocie „Żydów, Polaków, Cyganów". Wiarygodność tych deklaracji wzmacnia według mnie ich prostota i „trzeźwość" oceny. Stefan Lipniak nie twierdzi, że kiedykolwiek doszło do

5 Por. Stefan Lipniak. Rozdział pierwszy, w: A. Dauksza Klub Auschwitz i inne kluby..., s. 15. 
zrównania szans życiowych czy do zniesienia podziałów, przeciwnie - wielokrotnie przyznaje, że w najlepszym przypadku relacje ograniczały się do form bycia „razem/osobno" ${ }^{\text {: }}$

Tam reżim niesamowity, oddzielne baraki mieliśmy, Cygany, Żydy, Polacy. Nie mieszało się ich razem, zupełnie oddzielnie. Z Żydami spotykaliśmy się na robotach [...]. Żydy byli zawsze oddzielnie. Nigdy tak blisko między Polakami a Żydami nie było. [...] była zasadnicza różnica. Zawsze jest tak: Żydzi byli na śniadanie, a Polacy na obiad. Żydów najbardziej niszczyli. Polaków też, ale może mniej. Ale jak się wpadło na esesmana, to jednakową śmiercią mogliśmy umierać. [...] [Żydzi mieli - przyp. A.D.] dużo gorzej. Ich mordowali bez przerwy. Jak tylko mogli, tak niszczyli Żydów. Żydzi to byli podludzie. Holokaust miał zniszczyć rasę żydowską, rozumie to pani? A dopiero na drugim miejscu byli Polacy. No, jeszcze przed Polakami Cyganie, Romowie. ${ }^{7}$

Analizując wielogodzinne nagrania i zapisy rozmów ze Stefanem Lipniakiem, stwierdzam, że deklarowany ze wstydem antysemityzm przedwojenny słabnie czy wręcz zostaje zniwelowany podczas pobytu w obozie, nie jest także wyczuwalny w opowieści o późniejszym, „poobozowym” życiu. W wypowiedziach Lipniaka pobrzmiewa natomiast pewna osobliwa nostalgia: „Żyd był lepszy od nas, szkoda, że nie ma".

Wiele wątków domaga się tu analizy, jednak najważniejsze wydaje się zwrócenie uwagi na paradoks czucia i myślenia Stefana Lipniaka, który równocześnie wstydzi się przedwojennej, „trzebińskiej” zazdrości, współczuje Żydom obozowym i wreszcie deklaruje, że zazdrości Żydom Holokaustu i to Żydom, których po wojnie rzekomo „nie ma”. Nasuwa się natychmiast pytanie, dlaczego zazdrości, skoro „nie ma komu”?

Wiele wskazuje, że mimo dwuznaczności tego wyznania mój rozmówca nie jest anegdotycznym Polakiem, który „zazdrości Żydom wszystkiego, włącznie z Zagładą". W tym przypadku miejsce przedwojennego antysemityzmu opartego na resentymencie i przekonaniu o nierówności ekonomicznej zajęło zgoła inne wyobrażenie. Jeśli przed wojną lokalni Żydzi byli dla wielu Polaków faktycznym uosobieniem odmienności i jako tacy stanowili podstawowy, tożsamościowy punkt odniesienia - byli „obcy”, ale jednocześnie

6 Z. Bauman Razem/osobno, przeł. T. Kunz, Wydawnictwo Literackie, Kraków 2007.

7 Por. Stefan Lipniak. Rozdział pierwszy, w: A. Dauksza Klub Auschwitz i inne kluby..., s. 16-17. 
jakoś „swoi” - to w coraz bardziej monokulturowej rzeczywistości PRL-u owo poczucie było stopniowo wypierane umacnianym przez propagandę przeświadczeniem o nieobecności Żydów „znanych”, „krajowych” i trudnej do zdefiniowania obecności Żydów „odległych”, pozostających poza granicami Polski. Choć złożoność ówczesnych motywacji i projekcji jest frapująca, nie chcę w tym miejscu rozważać bogatego w bibliografię problemu zmiennych relacji polsko-żydowskich w latach 50., 60. i 70 .

Jednakże „zazdrość o Holokaust”, o której wspomina Stefan Lipniak, nie jest według mnie wariacją „przewidywalnego”, ,zwyczajowego" polskiego antysemityzmu. Problem wykracza też chyba poza "odwieczne" i „tradycyjne" polsko-żydowskie i żydowsko-polskie antagonizmy. Jest natomiast skutkiem m.in.polityki izolacji i antyżydowskiej nagonki komunistów, obejmuje również pokoleniowe oraz światopoglądowe konflikty „polsko-polskie”, a dotyczy przede wszystkim poczucia wydziedziczenia z pamięci. Kontekst wypowiedzi Stefana Lipniaka wskazuje, że chodzi o przeświadczenie o nieustabilizowaniu własnej i grupowej pozycji w symbolicznym, narracyjno-pamięciowym polu. Wiąże się z tym brak charakterystycznego i swoistego określenia polskiego doświadczenia obozowego, co stanowi zarazem podwalinę problemu, jak i sam "szczyt" góry lodowej narastających przez lata frustracji, rozczarowań i upokorzeń. Brak nazwy czyni to doświadczenie w jakiś sposób niezauważalnym, wszakże - jak wiadomo - „nienazwane nie istnieje dla nas”. Terminologiczny impas marginalizuje czy neutralizuje losy byłych więźniów, utrudniając nasze pamiętanie i stępiając wrażliwość.

Co więcej, „polski” brak nazwy przeciwstawiany jest terminowi Holokaust, który wydaje się „mocny”, gdyż sprawczo oddziałuje na kulturę i jednoznacznie kojarzy się z drugowojennym ludobójstwem Żydów. Analogicznie oddziałuje zresztą pojęcie Zagłady, która - stosowana „bezepitetowo" - obecnie w oczywisty sposób odnosi się do Shoah.

Przejawy problemu widać także w nazewnictwie związków i stowarzyszeń scalających „przeżywców”. W Polsce funkcjonują np.: Polski Związek Byłych Więźniów Politycznych Hitlerowskich Więzień i Obozów Koncentracyjnych, Stowarzyszenie Polaków Poszkodowanych przez III Rzeszę, Stowarzyszenie Więźniów Byłych Dzieci Hitlerowskich Obozów Koncentracyjnych, Stowarzyszenie Dzieci Zamojszczyzny Ofiar Prześladowań, Represji i Odosobnienia w Obozach Hitlerowskich w czasie II Wojny Światowej, Klub Byłych Jeńców Obozu Koncentracyjnego dla Kobiet Ravensbrück, Wielkopolskie Stowarzyszenie Kombatantów RP Osób Represjonowanych i Ich Rodzin, Stowarzyszenie Byłych Dzieci Więzionych w K.L. Auschwitz-Birkenau Na Których 
Dokonywano Pseudomedyczne Eksperymenty, Ogólnopolskie Stowarzyszenie Więźniów Byłych Dzieci Niemowląt Hitlerowskich Obozów i Zakładów Eksterminacji itd.

Ewidentnie wielosłowie i językowa nieporadność zastępują elementarny brak „wspólnego mianownika”. Mnogość oraz rozproszenie stowarzyszeń oddają bardziej zasadnicze podziały w obrębie tych środowisk. Co więcej, trudno oprzeć się wrażeniu, że bardzo długie, opisowe nazwy nie są funkcjonalne. Jednak w zamyśle twórców zapewne mają odgrywać zgoła inne role: z jednej strony ekskluzywnie wyznaczać ramy danej wspólnoty doświadczeń, z drugiej - informować pozostałych nie tyle nawet o statusie ofiar czy o zakresie kompetencji danej organizacji, ile o samym istnieniu danego zjawiska historycznego, jak np. pseudomedyczne eksperymenty, obecność dzieci w obozach koncentracyjnych czy nazistowskie represje na Polakach. Najwyraźniej te długie nazwy nie mają służyć przedstawicielom danej grupy, ale społeczeństwu - w założeniu skupiają „ludzi po przejściach”, by czynić ich świadectwo słyszalnym i widocznym. W praktyce jednak nieprzystępność nazewnictwa i lokalność oddziaływania organizacji przyczyniają się do społecznej obojętności.

Z pewnością jest wiele przyczyn polskiej niemożności (samo)identyfikacji. Problem rozpoczął się właściwie już w momencie wyzwalania obozów, zwłaszcza Auschwitz-Birkenau, ze względu na tryb jego funkcjonowania w świadomości Polaków - także podczas okupacji - oraz powojenny, symboliczny status tego obozu wyobrażanego jako epicentrum nazistowskiego ludobójstwa w polskiej i międzynarodowej opinii publicznej ${ }^{9}$. Władze komunistyczne błyskawicznie przejęły dominację w kształtowaniu polityki pamięci - Oświęcim czy raczej „Oświęcim” szybko stał się podwójnym znaczącym - z jednej strony miał dobitnie przypominać o krzywdzie narodu polskiego doznanej od Niemców, z drugiej, miał sankcjonować relacje między Polską i Związkiem Radzieckim jako wyzwolicielem ${ }^{10}$. Specyficznym sposobom

8 Por. F. Piper Zagłada, w: W. Długoborski, F. Piper Auschwitz 1940-1945. Węzłowe zagadnienia z dziejów obozu, t. 3, Wydawnictwo Państwowego Muzeum Auschwitz-Birkenau, Oświęcim 1995, s. 37.

H. Świebocki Ruch oporu. Wybrane zagadnienia, w: W. Długoborski, F. Piper, Auschwitz 1940-1945..., t. 4 .

M. Kucia Auschwitz jako fakt społeczny. Historia, współczesność iświadomość społeczna KL Auschwitz w Polsce, Universitas, Kraków 2005, s. 232-234.

9 Tamże, s. 229-312.

10 Tamże, s. 235. 
upamiętnienia towarzyszyła adekwatna retoryka umniejszania, bagatelizowania lub uniwersalizowania niektórych ofiar - zwłaszcza żydowskich i romskich - oraz zwielokrotnienia innych, szczególnie polskich. W początkowym okresie ścierały się jeszcze różne tendencje - radziecka komisja śledcza zapoczątkowała używanie kategoryzacji narodowo-państwowej, polskie instytucje decydowały się na kategoryzację pierwotną, zaś Trybunał norymberski preferował ujęcie uniwersalne, mówiąc o bliżej nieokreślonej „ludzkości”"1. Jak wskazuje Marek Kucia, w latach 1945-1947 wykształciło się obowiązujące przez ponad czterdzieści lat oficjalne polskie stanowisko kwalifikacji ofiar obozu Auschwitz oparte na kryterium narodowo-państwowym i akcentujące przede wszystkim straty wśród obywateli polskich, w domyśle włączając w tę liczbę Żydów obywatelstwa polskiego ${ }^{12}$.

Innym problemem utrudniającym wymianę doświadczeń były postawy społeczne i sytuacja polityczna. Początkowo dominował, zdaje się, typowy dla jednostek cierpiących na zespół stresu pourazowego opór czy w niektórych przypadkach wprost niemożność świadczenia, a co za tym idzie nazywania swoich przeżyć. Z czasem jednak - gdy przynajmniej teoretycznie zwiększała się gotowość do opowiadania - byli więźniowie napotykali szereg innych trudności. Po pierwsze, w straumatyzowanym społeczeństwie powojennym prawie nikt nie czekał na te opowieści ${ }^{13}$. Po drugie, nie wszyscy mogli i chcieli mówić w realiach PRL-owskich - głównie ze względów światopoglądowych, co dotyczyło zwłaszcza represjonowanych przez władze komunistyczne więźniów politycznych, m.in. czynnych podczas okupacji w strukturach Armii Krajowej. Po trzecie, nie bez znaczenia była ogromna nieufność społeczna, niechęć mówienia, ale i słuchania. „Przeżywcy”, nawet jeśli opowiadali o swoich doświadczeniach, czynili to przeważnie w gronie najbliższych i zaufanych, wskutek czego nie zachowały się zapisy tych narracji. Jeszcze inną kwestią było oddziaływanie propagandy na interpretację i sposób oceny zdarzeń oraz na dobór faktów i samych słów - ci, którzy decydowali się świadczyć, mniej lub bardziej świadomie uwewnętrzniali retorykę partyjną albo też celowo dostosowywali swoje opowieści do oficjalnej linii narracyjnej, np. przemilczając wątki żydowskie.

11 Tamże, s. 182.

12 Tamże, s. 181-184.

13 Jak wiadomo, prawidłowość nie dotyczyła wyłącznie społeczeństwa polskiego. Skrajnym przypadkiem był po wojnie tryb funkcjonowania żydowskich ocalonych w społeczeństwie izraelskim. 
Konsekwentne manipulacje propagandowe, „uniwersalizacja”, a następnie "unarodowienie" ofiar obozów bez wskazania na zróżnicowanie etniczne, marginalizacja zagłady Żydów i Romów oraz faktyczne działania zmierzające do kulturowego zunifikowania społeczeństwa, zwłaszcza nagonka na Żydów i w konsekwencji fala emigracji osiągająca kulminację w 1968 roku, doprowadziły do stanu, w którym polscy "przeżywcy” prawdopodobnie nie odczuwali realnej potrzeby dalszej specyfikacji swojego statusu „ofiar nazizmu”. W PRL-owskiej monokulturze pamięci „bezprzymiotnikowe" doświadczenie obozu stało się w pełni jednoznaczne i czytelne. Co więcej, złuda osamotnienia w polu pamięciowym pozwalała trwać społeczeństwu w mniemaniu, że to Polacy byli najważniejszą czy najliczniejszą grupą prześladowanych w obozach koncentracyjnych. W znacznym stopniu umacniała w tym poczuciu literatura tematyzująca czas okupacji, edukacja szkolna kolejnych pokoleń oraz nielicznie powstające analizy problemowe $\mathrm{e}^{14}$. Nie istniała praktycznie żadna znacząca konkurencja w kształtowaniu ówczesnej polityki pamięci, nie było również silnych kontrnarracji15. Izolacja społeczeństwa doprowadziła do braku konfrontacji z „nosicielami” lub nośnikami przeciwpamięci, a ewentualni przeciwświadkowie wywodzili się przeważnie z tej samej formacji. W konsekwencji duża grupa osób identyfikujących się jako polskie ofiary hitlerowskich represji nie miała faktycznego punktu odniesienia w postaci znaczącej inności, której można by przeciwstawiać własne opowieści oraz repertuar doświadczeń i form komemoracji. Jednym ze skutków była niemożność spojrzenia na własną wspólnotę jako na jedność odmienną od jakiejś innej jedności kulturowej czy etnicznej, co zapewne doprowadziłoby do konieczności wypracowania nadrzędnego terminu identyfikującego polskie doświadczenie. Podobnie zresztą z klasyfikacją i nazewnictwem byłych więźniów - w sytuacji, gdy rzekomo „wszyscy wiemy, jak było", innowacyjność terminologiczna okazuje się zbędna. Siłą rzeczy również wyrazistość i atrakcyjność przedstawiania narracji była problem wtórnym.

14 Por. choćby książkę A. Pawełczyńskiej Żywa historia - pamięć i ocena lat okupacji, Wydawnictwo Radia i Telewizji, Warszawa 1977, oraz teksty literackie, w których centralną pozycję zajmuje polskie doświadczenie obozowe: Dymy nad Birkenau S. Szmaglewskiej, Z otchłani Z. Kossak-Szczuckiej, Pożegnanie z Mariq̨ T. Borowskiego i inne.

Próby zaistnienia narracji niezgodnych z oficjalną linią były duszone w zarodku - np. stało się tak w przypadku Wielkiej Encyklopedii Powszechnej PWN, która w 1966 roku informowała, że nie Polacy, lecz Żydzi byli główną ofiarą obozów nazistowskich, co wywołało zdecydowany sprzeciw władz oraz doprowadziło do krytyki autorów i usunięcia tego fragmentu tekstu. 
Jeszcze jednym efektem monokulturowości jest wielość polskich stowarzyszeń skupiających byłych więźniów - stowarzyszeń o często zbliżonym profilu. W ramach tego podziału na mikrowspólnoty możliwe było „prokurowanie” inności, odgrywanie „kontrolowanej” odmienności i kultywowanie różnic symbolicznych - jakkolwiek nie byłyby one „drobne” czy „nieznaczące”. Ofiary nazizmu dzieliły się więc na liczne podgrupy, a przez kilkadziesiąt lat trwania PRL-u pączkowały kolejne kluby, zrzeszenia, związki, koła i stowarzyszenia o coraz bardziej rozbudowanych i szczegółowych nazwach. Grupowano się np. według płci, miejsca pochodzenia, miejsca uwięzienia, miejsca zamieszkania po wojnie, wieku, przekonań politycznych, „unikalnych" doświadczeń itd. Wielce prawdopodobne, że antagonizmy między reprezentantami tych inicjatyw motywowane były właśnie potrzebą odgrywania i odczuwania różnicy. Stan rzeczy zmienił się gwałtownie dopiero w latach 8o., gdy ta hermetyczna wspólnota pamiętania raz na zawsze straciła „monopol na obozy”.

\section{"Oświęcim" $\neq$ Auschwitz}

Kierunek zmian wyznaczył przede wszystkim „konflikt o Karmel”, czyli spór wywołany zajęciem przez siostry karmelitanki budynku "starego teatru” będącego jednym z obiektów byłego obozu Auschwitz-Birkenau. Zaanektowanie przestrzeni przez wspólnotę chrześcijańską i plany założenia klasztoru w tym miejscu wywołały wzburzenie w międzynarodowych środowiskach żydowskich, wskutek czego od 1985 do 1993 roku z różną częstotliwością pojawiały się kolejne protesty, spory i ostre w tonie publikacje ${ }^{16}$. Według Marka Kuci to właśnie w toku tych dyskusji Polakom niejako mimochodem stopniowo „ukazywały się" trzy podstawowe fakty: „Auschwitz jest dla Żydów symbolem zagłady ich narodu podczas II wojny światowej”, ,Zagłada dokonała się w dużej mierze w tym obozie”, „Żydzi byli największą grupą jego ofiar"17.

Nie będzie przesadą określenie tego „objawienia” mianem ciosu, na które polskie społeczeństwo nie było w połowie lat 8o. przygotowane. Szybko pojawiły się zresztą kolejne konflikty, polemiki i sposobność do fundamentalnych dyskusji o różnicy między polskim wyobrażeniem o "Oświęcimiu”

16 Por. T. Cebulski Auschwitz po Auschwitz. Historia, polityka i pamięć wokół Państwowego Muzeum Auschwitz-Birkenau 1980-2010, Libron, Kraków 2016, s. 148-159. 
a żydowskimi „prawami” do Auschwitz. Zapewne polskiej opinii publicznej mogło się wówczas wydawać, że skala dotychczasowych zafałszowań nie mogła być tak przytłaczająca, a nowa wiedza o obozach, odsłaniająca się z zagranicznych i coraz częściej także krajowych publikacji, nie jest „prawdziwa”, ale podyktowana presją żydowskich instancji. Ostatecznie odkłamywanie historii i statystyk wiązało się ze zmianami ustrojowymi. Przełomowa okazała się zwłaszcza rewizja kategorii i liczby ofiar. Stało się jasne, że „straty narodu polskiego" wcale nie są największe, gdyż głównymi poszkodowanymi są Żydzi, a następnie - oprócz Polaków - także Romowie i jeńcy radzieccy. Wrażenie na ówczesnym społeczeństwie robiły nie tylko dane o pochodzeniu ofiar, ale i radykalne obniżenie statystyki śmierci - w przypadku Auschwitz-Birkenau z szacowanych przez Państwowe Muzeum 2,8-4 milionów (w obiegowych opiniach urastające nawet do 4-7 milionów) do faktycznych 1,5 miliona ofiar. Dla wielu nowe fakty były tym trudniejsze do przyjęcia, że „przeszacowanie” liczby ofiar nie wynikało jedynie z radzieckiej propagandy, ale także z relacji przedstawianych przez samych ocalonych ${ }^{\mathbf{1 8}}$.

W krótkim czasie doszło więc do radykalnych przeobrażeń w obowiązującej narracji. Zmieniły się praktycznie wszystkie współrzędne, które mieli lub do których przyzwyczaili się Polacy. Okazało się, że miejsce dotychczas jednoznacznie utożsamiane z „Oświęcimiem” w zagranicznej świadomości funkcjonuje jako Auschwitz, a wokół jednej i tej samej przestrzeni ogniskują się różne rodzaje pamięci i różne rytuały. Symbol „Oświęcimia”, który był

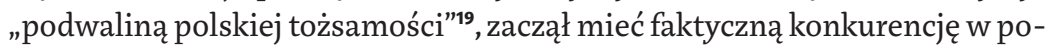
staci wcale nietożsamego symbolu „Auschwitz”.

Co więcej, wskutek międzynarodowego i krajowego przypływu zainteresowania obozową historią negowano nie tylko dane „ilościowe" i „jakościowe" dotychczasowej wiedzy o ofiarach, ale również formy ich upamiętnienia. Skrajnym przejawem była „wojna o krzyże”, która z całą mocą ukazała Polakom niezgodę Żydów na postępującą od lat 70. chrystianizację obozu ${ }^{20}$.

18 O procesie trudnego „uzgadniania” tych statystyk por. M. Kucia Auschwitz jako fakt społeczny..., S. $148-162$.

19 J. Nowak Społeczne reguły pamiętania. Antropologia pamięci zbiorowej, Nomos, Kraków 2011, S. 131.

20 Faktycznie od 1971 roku, kiedy doszło do beatyfikacji ojca Maksymiliana Kolbego, można mówić o postępującej chrystianizacji symboliki obozu Auschwitz-Birkenau, która osiągnęła punkt kulminacyjny podczas wizyty na terenie byłego obozu papieża Jana Pawła II w 1979 roku. Od lat 8o. ten stan rzeczy był coraz silniej krytykowany przez środowiska żydowskie, a w konsekwencji doprowadził do kilku znaczących sporów, jak konflikty o: klasztor karmelitanek, kościół 
Rozgrywające się w kolejnych latach konflikty - jak spór o „supermarket” czy o "dyskotekę"21 - były również reakcją na polonizację pamięci, ale też stanowiły pokłosie nieustabilizowanego nazewnictwa oraz niejasności w rozgraniczeniu przestrzeni „obozowej” i... tej mniej „obozowej”, czyli symbolicznego oddzielenia terenów oraz obiektów przynależnych Państwowemu Muzeum Auschwitz-Birkenau i miastu Oświęcim²2.

W konsekwencji intensywne konflikty rozgrywające się od połowy lat 8o. niemal do końca lat 90. - niejednokrotnie niepotrzebnie podsycane ostentacyjną retoryką mediów - doprowadziły do przeświadczenia o utracie kontroli Polaków nad formami upamiętnienia ofiar nazistowskiego ludobójstwa. Niezależnie od faktycznej zasadności argumentów strony żydowskiej polskie społeczeństwo lat 8o. - nieprzyzwyczajone do odbioru kontrnarracji oraz nieprzystosowane do merytorycznej dyskusji - uznało pamięć Żydów nie za komplementarną, ale za konkurencyjną do polskiej pamięci, a ich działania komemoratywne za otwarcie agonu nie tylko w polu symbolicznym.

Wskutek oddziaływania wielu czynników, jak długoletnia propaganda komunistyczna, antysemityzm, wyparcie, martyrologia polska, chrystianizacja i polonizacja obozów czy potrzeba epatowania własnymi krzywdami, wśród znacznej liczby Polaków dominowało poczucie, że historia obozów koncentracyjnych jest przede wszystkim ich historią. Jak słusznie zauważa Marek Kucia, „zaistnienie i utrwalenie się wśród Polaków takiej świadomości społecznej dotyczącej obozu utrudniało lub wręcz uniemożliwiało przyswajanie nowych faktów i przyjęcie innej symboliki"23. Nieubłagane napieranie zrewidowanej narracji po 1989 roku było w istocie radykalnym przełomem w funkcjonowaniu polskiej świadomości zbiorowej, czego skutki odczuwalne są do dzisiaj, podobnie jak wciąż nieustabilizowana jest postawa Polaków wobec Żydów, obozów i wydarzeń II wojny światowej.

w Brzezince, symbole religijne na polu prochów, krzyż "papieski” i jego "obronę", "wojnę" na krzyże na żwirowisku itd. Por. np. M. Kucia Auschwitz jako fakt społeczny..., s. 52-58. -Birkenau por. T. Cebulski Auschwitz po Auschwitz..., s. 220-230; oraz G. Zubrzycki Krzyże w Auschwitz. Tożsamość narodowa, nacjonalizm i religia w postkomunistycznej Polsce, przeł. P. Tomanek, Nomos, Kraków 2014, s. 133-145. 


\section{Wymiar stygmatyzacji}

Dlaczego w tak wielkim skrócie i uproszczeniu opowiadam tę znaną większości historię obozów jako „faktu społecznego”? Otóż chcę sprowokować do pomyślenia i opowiedzenia jej jeszcze raz, ale na nieco innych prawach, mianowicie właśnie z perspektywy polskich ofiar obozów koncentracyjnych. Celowo rozróżniam tu byłych więźniów i społeczeństwo. Twierdzę bowiem, że przytoczona na wstępie wypowiedź Stefana Lipniaka w istocie nie jest wymierzona przeciwko Żydom, ale przeciwko polskiej wspólnocie.

Obecnie w obiegowych wyobrażeniach ci, którzy ocaleli, kojarzą się z „kombatanctwem" - starością, niedołężnością, patetycznymi lub dla odmiany przaśnymi uroczystościami upamiętniającymi, pychą i roszczeniową postawą oraz nieatrakcyjnymi narracjami. Słowem - polscy „przeżywcy” są niemodni i jako tacy są marginalizowani w sferze publicznej. „Wykorzystuje” się ich „przy okazji”, najczęściej raz do roku, gdy są „używani” jako reprezentanci danego faktu historycznego. Najczęściej jednak na ogół zapomina się o ich istnieniu.

Tymczasem - jakby wbrew logice i mechanizmom „epoki końca świadka” - ci ludzie wciąż funkcjonują - jeśli nie w sferze medialnej, to z pewnością w przestrzeni publicznej polskich miast. Dopiero dostrzeżenie tej obecności oraz spojrzenie na byłych więźniów obozów jako na czujących, świadomych ludzi o niewyobrażalnym wręcz rezerwuarze doświadczeń, ludzi, których ciała są żywymi archiwami historii, pozwala uświadomić sobie skalę społecznej obojętności i ignorancji.

Jednym z wymiarów jest aspekt socjalno-praktyczny. Można mówić o pewnej ignorancji władz - wszystkich kolejnych władz - i organów państwowych względem tych, którzy przeżyli. Najbardziej wymiernym przejawem są topniejące ulgi, odbierane zapomogi i przywileje społeczne, wciąż zmieniający się status prawny tych osób, zmniejszanie rent oraz brak pomocy psychologicznej. Choć dla większości "przeżywców” doświadczenie zniewolenia, ubezwłasnowolnienia, życia "nagiego" w stanie wyjątkowym ${ }^{24}$ to centralny punkt życiorysu, z którym do dziś nie potrafią sobie poradzić, to jednak prawie nikt z nich nie miał okazji korzystać z pomocy psychologicznej - ani po wojnie, ani dziśs.

Innym problemem jest brak zainteresowania społecznego. Byli więźniowie obozów koncentracyjnych wyraźnie akcentują poczucie odtrącenia przez kolejne pokolenia, które potęguje ich samotność, podwójną stygmatyzację

24 G. Agamben Co zostaje z Auschwitz. Archiwum i świadek (Homo sacer III), przeł. S. Królak, Sic!, Warszawa 2008. 
- starością i kombatanctwem - oraz przeświadczenie o „niewykorzystaniu” w sferze polityki pamięci.

Oprócz wymiaru społecznego i politycznego jest jeszcze poziom badawczo-kulturowy. Jakkolwiek paradoksalnie to brzmi, polscy "przeżywcy” są ofiarami archiwów. Wydaje się bowiem, że z pewnością wielokrotnie z nimi rozmawiano i rejestrowano ich świadectwa. Jednak niekoniecznie tak się działo, a wyobrażenie, że archiwa polskich opowieści wojennych wprost pękają w szwach, jest tylko złudzeniem. Z kolei w tych przypadkach, gdy zadano sobie trud rejestracji, najczęściej nigdy nie wracano do danych świadków i nie ponawiano rozmowy, odcinając możliwość obserwacji zmian postawy opowiadającego i ewoluowania pamięci.

Co więcej, wbrew pozorom nigdy nie było tak, że równie chętnie rozmawiano ze wszystkimi „przeżywcami”. W okresie PRL-u zależało to od ich pochodzenia, pozycji społecznej i wykształcenia, a także od przekonań politycznych. Wielu byłych więźniów, zwłaszcza politycznych, nie uczestniczyło po wojnie w procesach kształtowania pamięci kulturowej, nie udzielało wywiadów, nie spotykało się z młodzieżą, nie było zapraszanych na oficjalne uroczystości. Niektórzy tłumaczyli sobie ten brak zainteresowania niesprzyjającą sytuacją polityczną. Jednak, co ciekawe, zmiany ustrojowe nie przyniosły odmiany. Po 1989 roku ewentualne dowartościowanie tych osób przestało zależeć od ich światopoglądu - polscy ocaleni „demokratycznie" "poszli w odstawkę", gdyż - jak się okazało - w nowym, dynamicznie kształtującym się układzie nie było miejsca dla kombatantów z innego porządku. Z kolei umacniające się zwroty pamięciowe i kulturoznawcze wybrały innego bohatera narracji. Był nim Żyd, który trwale zają - skądinąd w pełni należne - miejsce w krajowych studiach nad pamięcią. W konsekwencji dziś wprost nie sposób wymienić setek i tysięcy powstających od początku lat 90. artykułów, książek naukowych, tekstów literackich, przedstawień, nagrań, filmów, wizualizacji i projektów artystycznych poświęconych Żydom i Zagładzie. Trudno też mówić o ich dysproporcji w stosunku do reprezentacji czy problematyzacji polskiego doświadczenia obozowego, gdyż w tej skali porównania te drugie praktycznie nie istnieją. Funkcjonuje co prawda kilka baz archiwizujących nagrania lub zapisy świadectw, jednak oprócz nielicznych opracowań brakuje analiz tych opowieści. Przenikliwie tę prawidłowość komentuje Piotr Filipkowski:

Opowieść o nieżydowskim, nieholokaustowym doświadczeniu obozowym - o obozach koncentracyjnych, a nie o obozach zagłady, by użyć tego 
symbolicznego i uproszczonego, choć ważnego rozróżnienia - pozostała opowieścią „starą," z „tamtego", powojennego czasu. Opowiedzianą kiedyś przez więźniów politycznych, osadzoną w innej kulturze pamięci. I dzisiaj już nie bardzo dającą się słuchać. Tamten język, w którym nauczyli się opowiadać, nie jest już rozumiany. To wszystko wydaje się dobrze znane, naukowo wyeksploatowane, badawczo nieatrakcyjne, niemodne. Nie widać więc wielu chętnych, którzy chcieliby przy tym obozowym doświadczeniu na chwilę się jednak zatrzymać. A jeszcze mniej takich, którzy spróbowaliby je na nowo opowiedzieć - językiem bardziej współczesnym, może lepiej zrozumiałym. ${ }^{25}$

Faktycznie, nie sposób oprzeć się wrażeniu, że mimo boomu pamięciowego panującego od co najmniej kilku lat w krajowych gremiach naukowych, problem polskich ofiar jest po prostu niemodny. Niby „oddano" go refleksji środowisk prawicowych, ale nawet w tych kręgach trudno zaobserwować faktyczne, przekładające się na rzetelne analizy zainteresowanie obozowymi wspomnieniami „przeżywców”. Tym samym wciąż słusznie rozrastające się i umacniające badania nad Zagładą nie idą w parze z namysłem nad polskim doświadczeniem bez nazwy. Werbalizowane przez Stefana Lipniaka przeświadczenie, że nigdy nie powstał termin adekwatny dla przeżyć niewpisujących się przecież ani w zakres Holokaustu, ani Zagłady, jest zatem objawem bardziej ogólnego wołania o uwagę.

Zależy mi na ukazaniu osobności polskich "przeżywców” - zarówno na tle polskiego społeczeństwa, jak i żydowskich świadków. Jest to bowiem stale i błyskawicznie kurcząca się grupa, która nigdy nie doczekała się emancypacji w polu kulturowym. I choć zapewne nie sposób mówić już o emancypacji jeszcze żyjących, nielicznych "ostatnich świadków”, to jednak wydaje się, że warto starać się o rewizję wyobrażeń o tych doświadczeniach. Ich opowieści stale pozostają w cieniu Holokaustu, historia jest „słaba”, , mała” ,, biedna”, nikt jej dziś nie potrzebuje ${ }^{26}$. Byli więźniowie nigdy nie mieli okazji poczuć się swobodnie ze swoimi narracjami, zawsze podlegali marginalizacji i instrumentalizacji. Po wojnie byli albo represjonowani przez władze komunistyczne lub „włączani” w oficjalny obieg i wykorzystywani jako „materialne” dowody

25 P. Filipkowski Historia mówiona i wojna..., s. 9.

26 Znamienny w tym kontekście jest tytuł, który Anna Janko nadała książce problematyzującej wojenne doświadczenia jej matki - por. A. Janko Mała Zagłada, Wydawnictwo Literackie, Kraków 2015. 
na skalę nazistowskich zbrodni albo też konsekwentnie ignorowani. Z kolei po 1989 roku umocniła się społeczna obojętność czy wręcz niechęć do kombatantów utożsamianych dwojako - ze stylistyką PRL-owską lub wręcz przeciwnie - z etosem patriotyczno-prawicowym. W konsekwencji „przeżywcy", wciąż straumatyzowani wojną, niepewni swojej pozycji w realiach komunistycznych, teraz - dla odmiany - trwają zdezorientowani zaktualizowaną wersją historii, w której, co prawda, jest dla nich miejsce na poziomie faktów, ale nie ma go na poziomie akceptacji społecznej i zainteresowania badawczego.

Co ciekawe, nawet gdy na chwilę stają się podmiotami namysłu, narzuca im się rolę, w której mają występować - najczęściej jako polscy nacjonaliści ${ }^{27}$ lub świadkowie Zagłady. Przypuszczalnie do takich skojarzeń przyczynił się w znacznej mierze film Shoah Claude'a Lanzmanna, który na całe lata konstytuował wizerunek Polaka jako - w najlepszym razie bezczynnego obserwatora ludobójstwa Żydów ${ }^{\mathbf{2 8}}$. Nie ulega wątpliwości, że wielu polskich więźniów faktycznie widziało i czuło wydarzającą się w ich obecności Zagładę, a polisensoryczne wspomnienia tamtych wydarzeń wracają na różnych prawach w ich opowieściach. Piotr Filipkowski określa to doświadczenie jako „osmalenie” Polaków. Rzeczywiście, dosłownie i w przenośni noszą oni w swoich ciałach i w pamięci wrażenia, zapachy, dźwięki, poruszenia i obrazy rozgrywającej się przemocy zadawanej Żydom i Romom.

Jednakże niesprawiedliwością wydaje się traktowanie polskich „przeżywców" wyłącznie jako świadków Zagłady i ignorowanie ich własnych doświadczeń, cierpień, narracji, fantazmatów i interpretacji. Z całą mocą trzeba też stwierdzić, że słynna koncepcja Raula Hilberga - trójkąt zależności między sprawcą, ofiarą i obserwatorem - nie jest adekwatny do opisu obozowych relacji ${ }^{29}$. Polscy więźniowie kacetów byli bowiem zarówno ofiarami przemocy nazistowskiej, jak i często świadkami zagłady Żydów i Romów, a niekiedy także przyczyniali się do cierpienia innych więźniów.

27

28 D. Głowacka Współ-pamięć, pamięć "negatywna” i dylematy przekładu w „wycinkach” z Shoah
Claude'a Lanzmanna, „Teksty Drugie” 2016 nr 6 .

29

R. Hilberg Sprawcy, ofiary, świadkowie. Zagłada Żydów 1933-1945, przeł. J. Giebułtowski, Cyklady,
Warszawa 2007.

Por. choćby sposób ujęcia proponowany przez G. Zubrzycki w Krzyże w Auschwitz....

O skomplikowanych losach i o wielu poziomach recepcji tego filmu - zarówno polskich, jak i „zachodnich” odbiorców por. zwłaszcza: G. Niziołek Lęk przed afektem, „Didaskalia” 2016 nr 131; 


\section{Przeżywcy $\neq$ Ocaleni. Propozycja na zakończenie}

Gdy Stefan Lipniak stwierdza: „my nie potrafiliśmy nazwać tego, co nas spotkało. Wojna, obozy, niewola? Tyle lat minęło, a my nie mamy nazwy" i konfrontuje polski "brak" $\mathrm{z}$ terminem Holokaust, w istocie nie deprecjonuje żydowskiej inwencji terminologicznej, ale krytykuje opieszałość, bezrefleksyjność i brak zainteresowania polskiej wspólnoty, owego „my”, z którym jednocześnie w pełni się identyfikuje. Niemożność nazwania od początku generowała i generuje wiele innych trudności, jak definiowanie swojej pozycji społecznej, identyfikacja grupowa, reprezentowanie narracji na arenie międzynarodowej czy słyszalność głosu.

Dopiero konfrontacja ze stanowiskiem Stefana Lipniaka uzmysłowiła mi istnienie tych problemów, a nasze wspólne próby znalezienia choćby „roboczych” rozwiązań przyniosły kolejne trudne pytania. Zdumiała mnie choćby najbardziej elementarna kwestia, która nie została ustabilizowana po wojnie: jakim mianem określać ludzi, którzy przeżyli? Najprostszym rozwiązaniem byłoby skorzystanie z oficjalnego nazewnictwa stowarzyszeń. Jednakże charakter, wielość i różnorodność określeń nie tylko szybko zniechęcają do takich wyborów, ale też sugerują, że użyto ich w zamian jakiegoś innego terminu, który mógłby celniej oddawać istotę zjawiska. Najczęściej funkcjonująca w literaturze przedmiotu wersja: polscy byli więźniowie obozów koncentracyjnych, jest nieporadnie opisowa, a w istocie także wtórnie stygmatyzuje, gdyż w obecnym wyobrażeniu bycie więźniem - nawet jeśli „byłym” - kojarzy się automatycznie z jakąś winą, będącą powodem uwięzienia.

Szukając innych terminów, zdałam sobie sprawę, że moi rozmówcy zupełnie nie utożsamiają się z określeniami „ocalony” czy „ocalały” stosowanymi najczęściej w przypadku Żydów. Mimo szeroko komentowanych i opisanych różnic między tymi wariantami „ocalenie” nadto kojarzy się z pasywnością, poza tym polscy byli więźniowie nie mówią nigdy, że „ocaleli” z obozu, lecz że „przeżyli". Pewnym rozwiązaniem mogłoby być więc zastosowanie terminu proponowanego przez Zygmunta Baumana - „przeżytnik”30. Jednak z kilku względów to pojęcie nie wydaje się trafne. Nie dość, że w polszczyźnie "przeżytnik” zbyt mocno kojarzy się z „przemytnikiem”, to jeszcze pobrzmiewa w tym słowie pewne domknięcie aktu, ukończenie procesu. Proponowany przeze mnie "przeżywca” silniej oddaje natomiast ciągłe,

30 Z. Bauman Świat nawiedzony, w: Zagłada. Współczesne problemy rozumienia i przedstawiania, red. P. Czapliński, E. Domańska, Poznańskie Studia Polonistyczne, Poznań 2009, s. 15-27. 
procesualne - minione i obecne - wydarzanie się życia. Sugeruje także, że przeżycie biologiczne wcale nie gwarantuje ocalenia wrażliwości, tożsamości i świadomości - zarówno tej indywidualnej, jak i zbiorowej.

\section{Abstract}

\section{Agnieszka Dauksza}

JAGIELLONIAN UNIVERSITY (CRACOW)

Experience without a Name: 'Oświęcim' $\neq$ Auschwitz

Dauksza examines the status of non-Jewish Polish concentration camp survivors. Their wartime experience and the way in which they functioned after the war has always been and continues to be different from the Jewish experience. Based on empirical studies, Dauksza argues that the problem is that their experience is 'an experience without a name': unable to name it, they are also unable to experience what happened to a significant group of Poles during the occupation. The question concerns not only actual former prisoners and their relatives - as the framework of post-memory transfer would suggest - but also individuals who for several years lived in fear of being deported, as well as those who witnessed the deportation of others, including Jews.

\section{Keywords}

survivors, Poles, Jews, concentration camps, memory 